\title{
CrimRxiv
}

\section{Community-Oriented Policing and Technological Innovations}

Georgios Leventakis, M. R. Haberfeld

Published on: Jul 01, 2018

DOI: $10.21428 / \mathrm{cb} 6 a b 371.65266692$

License: Creative Commons Attribution 4.0 International License(CC-BY 4.0). 
